\title{
Contribution of Microfinance Institutions in Empowering Women in Tanzania (A Case of Serengeti District Council)
}

\author{
Jumanne Mng'ang'a * Wakara Ibrahimu Nyabakora Robert Laurent Nyagali \\ Local Government Training Institute (LGTI), P. O. Box 1125, Dodoma, Tanzania \\ *E-mail of the corresponding author: mngangajumanne@gmail.com
}

\begin{abstract}
In Tanzania the position of women in terms of economic and social status has been low compared to men. Majority of women are poorer, have low education and suffer from traditions and customary beliefs. Thus, empowering women is one of the main issues in Tanzania and sub- Sahara Africa context. Microfinance services are considered to be the entry point towards empowering women in economic and social status. However, it is also considered that Microfinance Institutions are extorting money from poor women through high interest rates, causing higher social pressure and domestic violence. The study use quantitative and qualitative data from Serengeti District council at Mara region of Tanzania. The study used cross-sectional studies, whereby data was collected at a single point in time. In total 20 women participated in the survey. The data obtained was analyzed by using Statistical Package for Social Sciences (SPSS). The study found that, the impact of Microfinance Institutions on women empowerment is very crucial in Tanzania. Women members of Microfinance Institutions have more control over savings and income generated from the business, greater role in decision making, and greater contribution in household income. However, the women do not participate in decisions regarding inheritance of household assets. With this regard, microfinance institutions have more contribution in women empowerment.
\end{abstract}

Keywords: Microfinance, Institutions, Empowerment, Household, Decision making

DOI: $10.7176 / \mathrm{JAAS} / 63-06$

Publication date: April $30^{\text {th }} 2020$

\section{Acknowledgement}

We would like to thank Serengeti District council staff members for their willingness in participating fully in our discussion and data collection. Also our thanks to management and staff of Local Government Training Institute for their moral and material help during this research. Last but not least, our thanks to our family members and those who helped us directly or indirectly in preparing this research paper. We enjoyed your contributions, though we authors remain responsible for any material miss-statement.

\section{Introduction}

Despite the evidence which indicates that microfinance empowers women (Hunt et al 2002;

Sharma, 2007; Kaniz, 2003); there seems to be a debate in literature on its effectiveness. In Tanzania, few of the studies discussed the contribution of the microfinance institutions in empowering women (Kato, P. M \& Kratzer, J. 2013). The dilemma is whether access to microfinance per se has an explicit ability to empower women.

Empowerment is linked with individual situation, abilities and environment. Differences in literacy, property rights and social attitudes about women may limit impact outside of the immediate household (Cheston et al, 2002). Empowerment depends on program, design, market, and loans size (Littlefield et al, 2003; Sarangi, 2007; Mayoux's, 2000; Cheston et al, 2002). Microfinances are potentially harmful to women (husbands jealous of their wives' new financial power may lead to power struggles and hence violence), it can create a large debt and it is not universal in application (Swope, 2005). Women sometimes have little or no control over their loan, with the husband or male family members making all decisions either voluntarily or forcibly (Pitamber, 2003) which enforces patriarchal control over women's lives (Morduch and Haley, 2002).

Numerous Microfinance Institutions have been emerging in various parts of Tanzania including Serengeti district council. All of them are providing microfinance services to the poor including women with the view of poverty reduction and empowerment for women. Contribution of microfinance for women empowerment in Serengeti is not known clearly due to the fact that, women status and situation before being empowered is seems to be the same even after the empowerment. Due to this fact, the study examines the extent to which Microfinance Institutions services have been successful in delivery of their promise particularly targeting women empowerment in the study area. 


\section{Literature Review}

Maanen defines microfinance as banking the un-bankables, bringing credit, savings and other essential financial services within the reach of tens-or rather hundreds of millions of people who are too poor to be served by regular banks, in most cases because they are unable to offer sufficient collateral (2004). In this case, Microfinance can embrace a range of financial services that seek to meet the needs of poor people, both protecting them from fluctuating incomes and other shocks and helping to promote their incomes and livelihoods.

Microfinance Institutions refer to financial institutions which provide financial services to the poor who are typically excluded from the formal banking system for lack of collateral (Ledgerwood, 1998). The author asserts that, lack of access to credit is readily understandable in terms of the absence of collateral that the poor can offer conventional financial institutions coupled with the various complexities and high costs involved in dealing with large numbers of small amount of loan desired, often illiterate barriers through innovative measures such as group lending and regular savings schemes.

Empowerment is the ideal combination of change, choice, and power (Cheston et al, 2002). "Empowerment is bringing people on the outside of a decision process into it" (Rowlands, 1997). It is "the ability to obtain an income that enables participation in economic decision-making" (Rowlands, 1997). Individuals become empowered when they obtain, "the right to determine choices in life and to influence the direction of changes, through the ability to gain control over material and non-material resources" (Rowlands, 1997).

All above definitions contribute to different aspects of the concept, and point to the conclusion that empowerment is necessary for poor and marginalized women to improve their situation. In terms of gender and development, empowerment is perceived to be a progressive process rather than an end product. This process involves a transformation through which individual women and groups with little power gain the ability to make choices and decisions that affect the course of their lives (Cheston et al, 2002).

(Cheston et al. 2002, and URT 2011) assert that, Women empowerment is determined by women's involvement in decision making, change in self- confidence level, women's status, change in social and political participation, change in control over income, change in awareness of social issues and problems, and family relationship and domestic violence before and after the Microfinance Institutions programs

Kato, P. M \& Kratzer, J. noted that, due to marginalization of women, the empowerment of women is the global challenge because the lords (men) do not want to be under the said inferior (women) (2013). This was proven by Khan \& Noreen (2012) that, around $70 \%$ of women in the world are poor while approximately $60 \%$ of them in Tanzania live in absolute poverty.

There are about three perceptions on women empowerment and Microfinance. Basu (2006) in his study on Microfinance and Women Empowerment explain that; Women's access to savings and credit gives them a greater economic role in decision-making through their decision about savings and credit. Also, when women control decisions regarding credit and savings, they will optimize their own and the household's welfare; and, the investment in women's economic activities will improve employment opportunities for women and thus have a 'trickle down and out' effect.

\subsection{Empowerment Model}

Bartlett (2004) describe that, empowerment involves a transformation as seen in the model below.

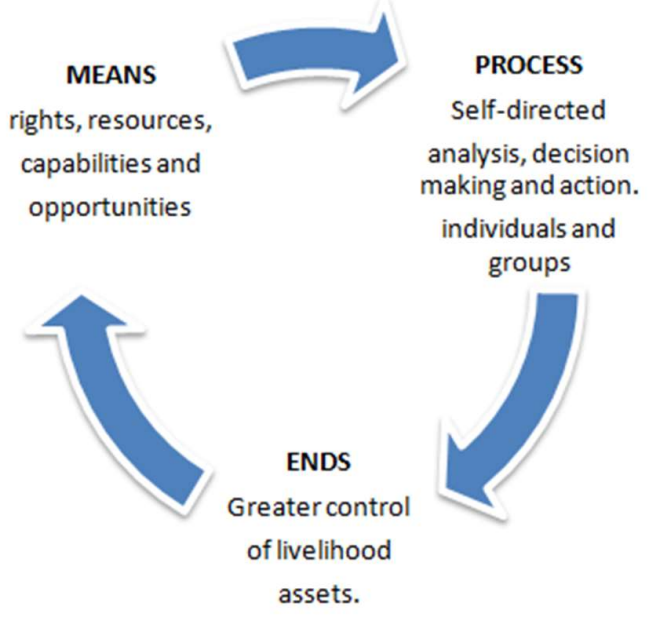

Fig 1: Transformation Model of Empowerment 
Empowerment needs all three transformation elements: means, process and ends. A change in means create the potential for a change in process. A change in process creates a potential for a change in ends. In many cases this transformation is cyclical, with a change in end brings about a further change in the means of empowerment (Bartlett, 2004).

Furthermore (Bartlett, 2004) continued describing that the range of means for empowerment is extremely wide, from national legal and political systems, to the savings and skills of villagers themselves. All of these things can provide the potential for empowerment. At the heart of empowerment is a process that people undertake by themselves.

\subsection{Importance of Microfinance to Women}

When women have access to financial services become more assertive and confident. Women become stronger in decision-making and even leadership within the families and communities. Studies have proved that Microfinance (having access to financial services) has improved women status within the families and the communities; example women nowadays own assets, including land, cars, and housing (Cheston et al, 2002).

\subsection{Negative Impacts of Microfinance on Women}

Goetz et al (1996) asserts that, both men and women assume risks when taking out a loan which becomes debt with all of its accompanying stresses and responsibilities. In addition some studies of the impact of microfinance programs have raised legitimate concerns about the potentially negative impact that programs can have on women, particularly in highly restrictive environments. One often reported concern is that clients' husbands or other household members take control of the woman's loans, yet the client herself retains responsibility for paying off the loans, thus increase her level of stress and dependency.

\section{Research Methodology}

The research uses a cross-sectional study, whereby the researchers collect data at a single point in time. Cross sectional studies take the form of questionnaire survey, with participants' selected using random sampling processes (Matthews and Ross, 2010). This design was preferred as in addition to its simplicity it allows determination of relationship between variables (Kothari, 2010). The design is further considered favorable in situations of limited resources and time as it was the case for the present study.

The study used structured interview and questionnaire tools as means of data collection. During the process, questions were asked orally to respondents and answers were recorded in the questionnaire sheets. This tool was chosen due to the fact that, it allows flexibility in the questioning process and give room for an interviewee to clarify things which are unclear. In addition, it reduces bias and brings more detailed response.

Questionnaires were prepared in Swahili and distributed to 20 different respondents at different time. Data analysis in general way involved a number of closely related operations which were performed with the purpose of summarizing the collected data and organizing these in such a manner that they answer research title. In this study we use descriptive data analysis, the reason of using this is that it provides us with profile of persons or other subject on any of a multiple of characteristics such as size, composition, efficiency, and preferences. The data that collected in this study was coded and analyzed by using Statistical Package for Social Sciences.

\subsection{Research Findings and Discussion}

\subsection{Social and Demographic Characteristics}

From table 1 below, about $70 \%$ of beneficiaries were married or cohabited, $20.0 \%$ were not married, $5 \%$ were divorced and $5 \%$ were widowed. This means that, a big number of empowered women are married and therefore may need the services of Microfinance institutions to be empowered to manage their homes. That's why the issue of clients' husbands or other household members take control of the woman's loans, yet the client herself retains responsibility for paying off the loans arise.

The tabulation below shows the marital status of respondents;

Table 1: Respondents' Marital Status

\begin{tabular}{|l|l|l|l|l|l|}
\hline \multicolumn{2}{|c|}{} & Frequency & Percent & Valid Percent & Cumulative Percent \\
\hline \multirow{4}{*}{ Valid } & Single & 4 & 20.0 & 20.0 & 20.0 \\
\cline { 2 - 6 } & Married & 14 & 70.0 & 70.0 & 90.0 \\
\cline { 2 - 6 } & Divorced & 1 & 5.0 & 5.0 & 95.0 \\
\cline { 2 - 6 } & Widowed & 1 & 5.0 & 5.0 & 100.0 \\
\cline { 2 - 6 } & Total & 20 & 100.0 & 100.0 & \\
\hline
\end{tabular}

Source: Field Data 


\subsection{Education Level}

The highest level of education most mothers have attained is secondary education with $(50 \%)$, followed by primary education (35\%), and $15 \%$ at post secondary education. Most of the women engaged in this study also had at least basic education. The tabulation below shows the highest level of education of the women.

Table 2: Respondents' Education Level

\begin{tabular}{|l|l|l|l|l|l|}
\hline \multicolumn{2}{|c|}{} & Frequency & Percent & $\begin{array}{l}\text { Valid } \\
\text { Percent }\end{array}$ & $\begin{array}{l}\text { Cumulative } \\
\text { Percent }\end{array}$ \\
\hline \multirow{4}{*}{ Valid } & Primary Education & 7 & 35.0 & 35.0 & 35.0 \\
\cline { 2 - 6 } & Secondary education & 10 & 50.0 & 50.0 & 85.0 \\
\cline { 2 - 6 } & Post-secondary Education & 3 & 15.0 & 15.0 & 100.0 \\
\cline { 2 - 6 } & Total & 20 & 100.0 & 100.0 & \\
\hline
\end{tabular}

Source: Field Data

\subsection{Extent of Microfinance Institutions' Contribution on Women Empowerment}

The objective of this item is to asses if there are contributions played by Microfinance Institutions' in empowering women economically. The researchers asked respondents to give their assessment on the extent of Microfinance Institutions' contribution on women empowerment. Majority (85\%) of respondents shows their appreciation on the contribution of microfinance institutions in women empowerment, while only $15 \%$ of them said that microfinance institutions have no contribution to women empowerment. The feedback from respondent was presented as shown below.

Table 3: Extent of Microfinance Institutions' Contribution on Women Empowerment

\begin{tabular}{|c|c|c|c|c|c|}
\hline & & Frequency & Percent & Valid Percent & $\begin{array}{c}\text { Cumulative } \\
\text { Percent }\end{array}$ \\
\hline \multirow{6}{*}{ Valid } & Very poor amount & 1 & 5.0 & 5.0 & 5.0 \\
\hline & Bad amount & 2 & 10.0 & 10.0 & 15.0 \\
\hline & Satisfactory amount & 5 & 25.0 & 25.0 & 40.0 \\
\hline & Good amount & 6 & 30.0 & 30.0 & 70.0 \\
\hline & Excellent amount & 6 & 30.0 & 30.0 & 100.0 \\
\hline & Total & 20 & 100.0 & 100.0 & \\
\hline
\end{tabular}

Source: Field Data

\subsection{Empowered Women Contribution to Household Income}

To assess the empowered women contribution to the household income the researchers asked respondents to give their perceptions. On this item, the researchers graded the performance by, Tsh 1 to 20,000 poor, 20,001 to 100,000 satisfactory and 100,001 and above means Excellent. The results shows majority (70\%) of women have poor contribution to household income regardless of being empowered, while $30 \%$ of them have excellent contribution to the household. The results are consistence with the previous study by Basu (2006).

The feedback from respondent is presented as shown below.

Table 4: Monthly Contribution to the Household Income

\begin{tabular}{|c|c|c|c|c|}
\hline Amount (Tsh) & Frequency & Percent & Valid Percent & Cumulative Percent \\
\hline $1 /=\quad 20,000 /=$ & 6 & 30 & 30 & 30 \\
\hline $20,001 /=-100,000 /=$ & 8 & 40 & 40 & 70 \\
\hline $100,001 \quad$ and Above & 6 & 30 & 30 & 100 \\
\hline Total & 20 & 100 & 100 & \\
\hline
\end{tabular}

Source: Field Data 


\subsection{Participation of Empowered Women in Decision Making}

The objective of this survey is to assess the participation of women in decision making. The researchers asked respondents to give their views on the participation of empowered women in decision making. Majority of empowered women (about $80 \%$ ) participate in family income decision making, while about $20 \%$ of them have no decision on family income. The results are consistence with the previous study by Rowlands, 1997.

The feedback from respondent was presented as shown in the table below.

Table 5 (a) Decision over Family Income

\begin{tabular}{|rl|r|r|r|r|}
\hline & Frequency & Percent & Valid Percent & Cumulative Percent \\
\hline \multirow{3}{*}{ Valid } & Very little & 1 & 5.0 & 5.0 & 5.0 \\
& Little & 3 & 15.0 & 15.0 & 20.0 \\
& Normal & 8 & 40.0 & 40.0 & 60.0 \\
& Much & 5 & 25.0 & 25.0 & 85.0 \\
& Very much & 3 & 15.0 & 15.0 & 100.0 \\
& Total & 20 & 100.0 & 100.0 & \\
\hline
\end{tabular}

Source: Field Data

Table 5(b) below shows that regarding the family planning, majority of women $(70 \%)$ participates in family planning, while few of them $(30 \%)$ do not participate in such decisions. The findings are consistence with the previous study by Rowlands, (1997). The feedback from respondent was presented as shown in the table below.

Table 5(b): Decision on Family Planning Methods

\begin{tabular}{|ll|r|r|r|r|}
\hline & Frequency & Percent & Valid Percent & Cumulative Percent \\
\hline \multirow{3}{*}{ Valid } & Very little & 6 & 30.0 & 30.0 & 30.0 \\
& Little & 2 & 10.0 & 10.0 & 40.0 \\
& Normal & 4 & 20.0 & 20.0 & 60.0 \\
& Much & 2 & 10.0 & 10.0 & 70.0 \\
& Very much & 6 & 30.0 & 30.0 & 100.0 \\
Total & 20 & 100.0 & 100.0 & \\
\hline
\end{tabular}

Source: Field Data

Table 5 (c) below shows that majority of women (65\%) do not participate in decision regarding right of inheritance of household assets, while few (35\%) participate. The feedback from respondent was presented as shown in the table below.

Table 5(c): Decision on Right of Assets Inheritance

\begin{tabular}{|c|c|c|c|c|c|}
\hline & & Frequency & Percent & Valid Percent & Cumulative Percent \\
\hline \multirow{6}{*}{ Valid } & Very little & 4 & 20.0 & 20.0 & 20.0 \\
\hline & Little & 1 & 5.0 & 5.0 & 25.0 \\
\hline & Normal & 3 & 15.0 & 15.0 & 40.0 \\
\hline & Much & 2 & 10.0 & 10.0 & 50.0 \\
\hline & Very much & 10 & 50.0 & 50.0 & 100.0 \\
\hline & Total & 20 & 100.0 & 100.0 & \\
\hline
\end{tabular}

Source: Field Data

\subsection{Assessment of Women Knowledge of Microfinance Institutions' Empowerment}

In table 6, researchers ask respondents to give their assessment on microfinance institutions' empowerment. Majority of women (65\%) do not have knowledge on the matter and so unable to join, while the few (35\%) knows and benefits from the empowerment. The feedback from respondent was presented as shown below. 
Table 6: Women Knowledge on Microfinance Institutions' Empowerment

\begin{tabular}{|l|l|l|l|l|l|}
\hline \multicolumn{2}{|c|}{} & Frequency & Percent & $\begin{array}{l}\text { Valid } \\
\text { Percent }\end{array}$ & $\begin{array}{l}\text { Cumulative } \\
\text { Percent }\end{array}$ \\
\hline \multirow{3}{*}{ Valid } & Have MFIs' Knowledge & 7 & 35.0 & 35.0 & 35.0 \\
\cline { 2 - 6 } & Do not have MFIs' Knowledge & 13 & 65.0 & 65.0 & 100.0 \\
\hline Total & 20 & 100.0 & 100.0 & \\
\hline
\end{tabular}

Source: Field Data

\section{Conclusion:}

The study has identifies the contribution of microfinance institutions on women empowerment. The research has accomplished the objectives by whether access to microfinance lead to women empowerment or not. This study therefore helps microfinance institutions' organizers and other stakeholders to strengthen the existing contribution of microfinance institutions to women.

From the findings, researchers answered the research title - contribution of microfinance institutions on empowering women using the questionnaire's questions which were answered by respondents.

Also the study revealed that, microfinance institutions have help women to make major expenditure like school bills, payment of rent, making bank saving, purchasing food, to have social network, to earn respect in the community and expanding their business. Furthermore, there are challenges facing women like high rate of interest, low level of education among of majority of women, not recognized in household assets inheritance, and poverty. The results are consistent with prior studies with the view that women's participation in microfinance services leads to an increased women's empowerment (Leach \& Sitaram, 2002; Pitt et al., 2006; Rai \& Ravi, 2011).

Furthermore, the findings show that there is a significant relationship between the participation in microfinance institutions and decision-making in the household. As the results indicate microfinance institutions create the opportunity for women to develop a greater voice in the home upon being recognized as earners of income and contributors to the household budget (Wrigley-Asante, 2011). Microfinance institutions provide an opportunity for women to set-up their own business and gets income to contribute and support their families which increases their role in decision-making. The contribution made by women strengthening women's position within the household and their role in decision making increased (Cheston \& Kuhn, 2002; Hashemi et al., 1996; WrigleyAsante, 2011); as stated by women during interviews that women in the past were not able to raise their voice in their families, simply because they had neither money nor any kind of economic activities.

The study has proved that there is lack of information to women in such a way that, many women who would be beneficiaries does not benefit; and so seem as if no impact of microfinance institutions' empowerment in Serengeti District, Mara Region. So this remains a case for further studies in the study area.

\section{REFERENCES}

Basu, J. P. (2006), Microfinance and Women Empowerment; An Empirical Study with Special Reference to West Bengal.

Bartlett, A. (2004). Entry Points for Empowerment. Bangladesh: CARE Bangladesh Cheston, S., \& Kuhn, L. (2002). Empowering Women through Microfinance. In S. Daley- Harris (Ed.), Pathways out of poverty: Innovation in Microfinance for the Poorest Familiars (pp. 167-228). Bloomfield, Connecticut: Kumarian Press.

Goetz, A. M., \& Gupta, R. S. (1996). Who Takes the Credit? Gender, Power, and Control over loan use in rural credit programs in Bangladesh. World Development, 24(1), 45-63.

Hashemi, S. M., Schuler, S. R., \& Riley, A. P. (1996). Rural Credit Programs and Women's Empowerment in Bangladesh. World Development, 24(4), 635-653.

Hunt, J., \& Kasynathan, N. (2002). Reflections on Microfinance and Women's Empowerment. Development Bulletin, 57, 71-75.

Kaniz, F. A. (2003): Microcredit as a Tool for Women Empowerment: The Case of Bangladesh, Development Studies, London School of Economics.

Kato, P. M \& Kratzer, J. 2013). Empowering Women Through Microfinance. Evidence from Tanzania. Journal of Entrepreneurship Perspectives. Vol. 2 Issue 1. P.31-59

Khan, R. E. A, \& Noreen, S (2012). Microfinance and Women Empowerment: A Case Study of District Bahawalpur (Pakistan). African Journal of Business Management, 6(12), 4514-4521 
Kothari-C-2010-Research-Methodology-Methods-and-Techniques-Mumbai-New-Age International publishers.

Leach, F., \& Sitaram, S. (2002). Microfinance and Women's Empowerment: A lesson from India. Development in Practice, 12(5), 575-588.

Ledgerwood, J. (1999) Sustainable Finance with the Poor, Micro Finance Handbook: An Institutional and Financial Perspective. Washington, D.C: The World Bank.

Littlefield, E., Murduch, J. and Hashemi, S. (2003), Is Microfinance an Effective Strategy to Reach the Millennium Development Goals?

Maanen, van Gert (2004) Micro Credit: Sound Business or Development Instrument, Voorburg, The Netherlands.

Matthews, B. and Ross, L. (2010) Research Methods. Pearson Longman, London.

Mayoux, L. (2002). Microfinance and Women's Empowerment: Rethinking 'Best Practice'. Development Bulletin, 57, 76-81

Morduch, J. and Haley, B. (2002), Analysis of the Effects of Microfinance on Poverty Reduction, NYU Wagner Working Paper No. 1014

Pitamber, S. (2003), Factors Impeding the Poverty Reduction Capacity of Micro-credit: Some Field Observations from Malawi and Ethiopia, Economic Research Papers No. 74, The African Development Bank

Pitt, M. M., Khandker, S. R., \& Cartwright, J. (2006). Empowering Women with Micro Finance: Evidence from Bangladesh. Economic Development and Cultural Change, 54(4), 791-831.

Rai, A., \& Ravi, S. (2011). Do Spouses Make Claims? Empowerment and Microfinance in India. World Development, 39(6), 913-921.

Rowlands, J. (1997). Questioning Empowerment. Oxford: Oxfam.

Sarangi, N. (2007), Microfinance and the Rural Poor: Impact Assessment Based on Fieldwork in Madhya Pradesh, India

Sharma, P. R. (2007), Micro-finance and Women Empowerment, The Journal of Nepalese Business Studies, Vol. IV No. 1.

Swope, T. (2005), "Microfinance and Poverty Alleviation", Partial Fulfillment of the Requirements of the Independent Study on Microfinance.

United Republic of Tanzania (URT). (2011). Gender. Retrieved from http://www.tanzania.go.tz/gender.html Wrigley-Asante, C. (2011). Out of the Dark but Not Out of the Cage: Women's Empowerment and Gender Relations in the Dangme West District of Ghana. Gender, Place \& Culture, 1-20. 